\title{
Environmental Impact Analysis of the Emission from Petroleum Refineries in Nigeria
}

\author{
Oladimeji T. E. ${ }^{1}$, Sonibare J. A. ${ }^{2}$, Odunfa K. M. ${ }^{3}$ \& Oresegun O. R. ${ }^{1}$ \\ ${ }^{1}$ Chemical Engineering Department, Covenant University, Ota, Ogun State Nigeria \\ ${ }^{2}$ Chemical Engineering Department, Obafemi Awolowo University, Ile-Ife, Nigeria \\ ${ }^{3}$ Mechanical Engineering Department, University of Ibadan, Ibadan, Nigeria \\ Correspondence: Oladimeji Temitayo Elizabeth, College of Engineering, Covenant University. Ota, Ogun State. \\ Nigeria. Email: temitayo.fatoki@covenantuniversity.edu.ng \\ Received: August 12, 2014 Accepted: August 15, 2014 Online Published: March 14, 2015 \\ doi:10.5539/eer.v5n1p33 URL: http://dx.doi.org/10.5539/eer.v5n1p33
}

\begin{abstract}
Health and environmental hazards, a thing of global concern have been the major characteristics of the petroleum refinery areas worldwide, Nigeria inclusive. This is as a result of the emissions from petroleum refineries which resulted into air quality degradation of the host environment. This problem which has equally affected the climatic conditions of the petroleum producing areas is more pronounced in Nigeria due to lack of implementing adequate policies to protect the host environment. This study is carried out to investigate the atmospheric conditions of the petroleum refineries and identify the environmental impact of emissions of criteria pollutants from the proposed project in the area of influence. Emission inventory of criteria pollutants was carried out on the four existing and twenty-three proposed petroleum refineries in Nigeria. Using no control-measure option, the estimated annual criteria air pollutants emissions from point sources in the existing refineries are 1,217 tons/annum for $\mathrm{PM}_{10}, 45,124$ tons/annum for $\mathrm{SO}_{2}, 167,570$ tons/annum for $\mathrm{NO}_{\mathrm{x}}, 3,842$ tons/annum for VOC and 242,469 tons/annum for $\mathrm{CO}$. An additional 1,082 tons/annum of $\mathrm{PM}_{10}, 168,944$ tons/annum of $\mathrm{SO}_{2}, 688,687$ tons/annum of $\mathrm{NO}_{\mathrm{x}}, 9,122$ tons/annum of $\mathrm{VOC}$ and 569,975 tons/annum of $\mathrm{CO}$ were predicted to be added into the Nigeria airshed by the proposed petroleum refineries. The highest pollutant emitting state was predicted to be Rivers State with the highest number of refineries while the least pollutant emitting states were predicted to be Kaduna, Edo, Lagos and Anambra States with only one refinery in each of the state. The ability to adopt appropriate control measures will determine the rate of emission of criteria pollutants released into the country's airshed.
\end{abstract}

Keywords: criteria air pollutants, emission factor, emission inventory, Nigeria, refinery

\section{Introduction}

Nigeria is the highest producing nation in Afica with production rate of 2.35 million barrel per day (bbl/dy) (Klieman, 2012). International Monetary Fund (IMF) establishes that oil and natural gas export revenue account for $96 \%$ of total revenue in 2012 , also it has been estimated that demand and consumption of petroleum in Nigeria grows at the rate of $12.8 \%$ annually, however, petroleum products are unavailable and expensive because a significant percentage of required petroleum products are imported while limited quantity is supplied to the nation due to instability in price and scarcity of the products. In view of this, it is necessary for the country to develop her refining potential (Sonibare et al., 2007). One of the strategies developed in Nigeria to increase her refining potential includes approval of more refineries to complement the existing ailing four state-owned refineries, which despite having a combine production capacity of 445,000 barrels per day (bpd), remain unable to meet the nation's petroleum products demand. Nigeria has four existing petroleum refineries (Table 1), while twenty-three proposed refineries (Table 2) have been licensed and are at various stages of completion (DPR, 2004; DPR, 2010). The more the refineries, the more the emissions generated, and the more dangerous it becomes on health and the environment which may result in degraded air quality of host environment, hence the need to control the rate of emissions in the refineries.

As petroleum refinery and petrochemical industries are most desirable for national development and improved quality of life, the unwholesome and environmentally unacceptable pollution effects of the waste from these industries are of major concern (Reinermann and Golightly, 2005). This is because, in the process of converting crude oil into petroleum and petrochemical products, wastes of different kinds are generated. These wastes are 
released to the environment in form of gases, particles and liquid effluent which becomes hazardous to the environment and to human health. Air emissions can come from number of sources within a petroleum refinery which include; equipment leaks (from valves, flanges, pump seals, drains and compressor seals), high-temperature combustion processes in the burning of fuels, the heating of steam and process fluids and the transfer of products. Numerous pollutants are emitted into the environment through normal emissions, fugitive releases, accidental releases or plants upsets from various refining operations such as separation, conversion and treatment processes (US DOE, 2007). About 900 cases of accidents in oil refining processes and exploration was reported in Nigeria in the year 2000 which is as a result of equipment failure and malfunctioning, deterioration and ageing of pipelines etc. Major components of these emissions are criteria air pollutants, which include particulate matter $(\mathrm{PM})$, oxides of nitrogen $\left(\mathrm{NO}_{\mathrm{x}}\right)$, sulphur dioxide $\left(\mathrm{SO}_{2}\right)$, carbon monoxide $(\mathrm{CO})$ and volatile organic compounds (VOCs).

From previous studies, the environmental and health implications of these pollutants cannot be overemphasized. During the past decades, criteria pollutants caused some health problems and damages to plants such as DNA breakdown in bone marrow cells, respiratory diseases and reduced lung function in humans (Zhongua et al., 2003), reduction of reproductive processes (Cape, 2003) in plants and formation of acid rain which deteriorates water quality and affect aquatic habitat (Johnson et al., 2003). About 2.5 million deaths per year was found to result from indoor exposures to particulate matter in rural and urban areas in developing countries, representing $4-5 \%$ of the 50-60 million global deaths that occur annually (WHO, 2002). The effects may not be confined to the local area of production but extend to regional as well as global scales due to possibility of long transportation (Mitra and Sharma, 2002).

This study aims at collection and collation of detailed information concerning the air pollutant emissions in existing and proposed petroleum refineries in Nigeria (Figure 1) using emission factor approach. This is for the purpose of determining the potential impacts of these emissions on air quality in Nigeria's airshed.

\subsection{Petroleum Refineries and Air Emission Sources}

A typical modern refinery takes in crude as feed through the heat exchangers (for temperature increase) and desalters (for salt water removal) into the atmospheric distillation column, where distillation process takes place under atmospheric pressure. In the distillation process, fractions get separated in increasing order of boiling points. The top products (highly volatile) get condensed in a reflux condenser with some portion of condensed fractions going back as reflux (Sonibare et al., 2007). Several other processes are required for the crude oil to be finally converted into the final products of different fractions. Several operations such as separation, conversion, treatments, feedstock and product handling involved in the petroleum refining process are potential sources of criteria air pollutants (James et al., 2001). The most significant point sources of emission in the petroleum refineries are fluid catalytic cracking units, steam boilers, process heaters, and flares. These sources emit various pollutants through catalytic cracking of hydrocarbons, combustions and equipment leaks of volatile compounds.

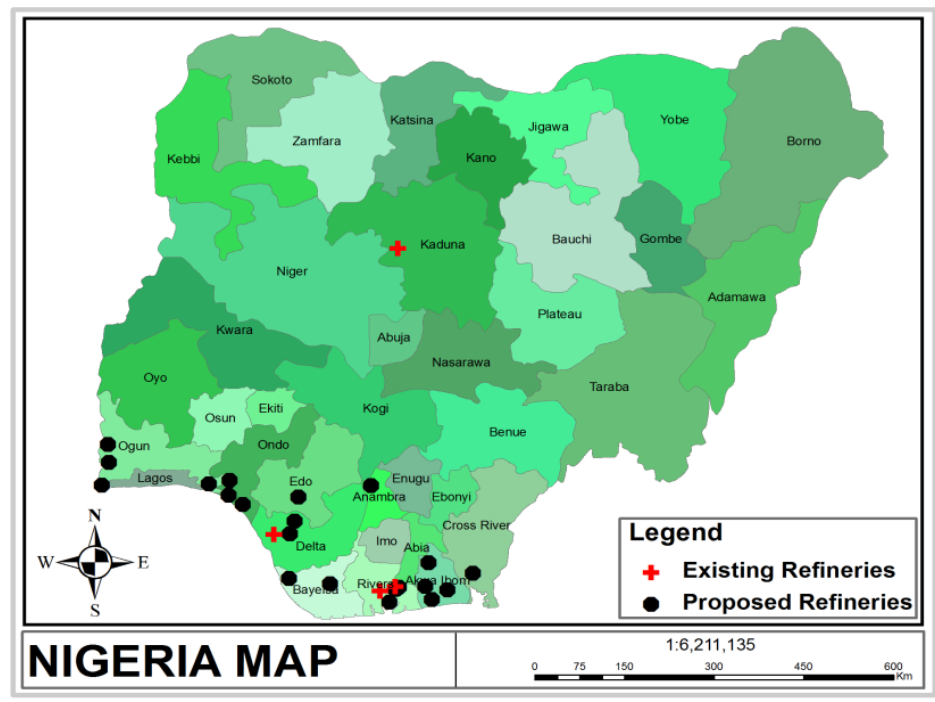

Figure 1. Existing and proposed petroleum refineries in Nigeria 
Table 1. Existing refineries in Nigeria

\begin{tabular}{|c|c|c|c|c|c|c|}
\hline \multirow[t]{2}{*}{$\mathrm{S} / \mathrm{N}$} & \multirow[t]{2}{*}{ Name of Refinery } & \multirow{2}{*}{$\begin{array}{l}\text { Capacity } \\
\text { (bbl/dy) }\end{array}$} & \multirow{2}{*}{$\begin{array}{c}\text { Year of } \\
\text { Production }\end{array}$} & \multicolumn{3}{|c|}{ Location } \\
\hline & & & & Town & L.G.A & State \\
\hline 1 & $\begin{array}{l}\text { Kaduna Refining \& } \\
\text { Petrochemical Company }\end{array}$ & 110,000 & 1980 & Kaduna & Chikun & Kaduna \\
\hline 2 & $\begin{array}{c}\text { Port Harcourt Refining } \\
\text { Company I }\end{array}$ & 60,000 & 1965 & $\begin{array}{c}\text { Port } \\
\text { Harcourt }\end{array}$ & Eleme & Rivers \\
\hline 3 & $\begin{array}{c}\text { Port Harcourt Refining } \\
\text { Company II }\end{array}$ & 150,000 & 1989 & $\begin{array}{c}\text { Port } \\
\text { Harcourt }\end{array}$ & Eleme & Rivers \\
\hline 4 & $\begin{array}{c}\text { Warri Refining \& } \\
\text { Petrochemical Company }\end{array}$ & 125,000 & 1978 & Warri & Effunrun & Delta \\
\hline
\end{tabular}

Source: DPR (2001)

Table 2. Proposed Refineries in Nigeria

\begin{tabular}{|c|c|c|c|c|c|c|}
\hline \multirow[t]{2}{*}{$\mathrm{S} / \mathrm{N}$} & \multirow[t]{2}{*}{ Name of Refinery } & \multirow{2}{*}{$\begin{array}{l}\text { Capacity } \\
\text { (bbl/dy) }\end{array}$} & \multirow{2}{*}{$\begin{array}{l}\text { Date of } \\
\text { issue }\end{array}$} & \multicolumn{3}{|c|}{ Location } \\
\hline & & & & Town & L.G.A & State \\
\hline 1 & $\begin{array}{c}\text { Amakpe International } \\
\text { Refinery }\end{array}$ & 12,000 & 2004 & $\begin{array}{l}\text { Ikot } \\
\text { Ekpene }\end{array}$ & Eket & Akwa Ibom \\
\hline 2 & Amexum Corporation & 100,000 & 2009 & Ikang & Akpabuyo & Cross River \\
\hline 3 & Antonio Oil & 27,000 & 2009 & Iwopin & Iwopin & Ogun \\
\hline 4 & $\begin{array}{c}\text { Chase Wood Consortium } \\
\text { Nigeria Limited }\end{array}$ & 70,000 & 2004 & Eket & Eket & Akwa Ibom \\
\hline 5 & Clean Water Refinery & 60,000 & 2004 & Onne & Eleme & Rivers \\
\hline 6 & $\begin{array}{c}\text { Gasoline Associate \& } \\
\text { International Limited } \\
\text { Refinery }\end{array}$ & 100,000 & 2009 & Ipokia & Ipokia & Ogun \\
\hline 7 & $\begin{array}{c}\text { Ilaje Refinery \& } \\
\text { Petrochemicals }\end{array}$ & 100,000 & 2004 & Ilaje & Ilaje & Ondo \\
\hline 8 & $\begin{array}{l}\text { Niger Delta Refinery \& } \\
\text { Petrochemical Limited }\end{array}$ & 100,000 & 2004 & $\begin{array}{l}\text { Niger } \\
\text { Delta }\end{array}$ & $\begin{array}{l}\text { Warri } \\
\text { South }\end{array}$ & Delta \\
\hline 9 & $\begin{array}{l}\text { NSP Refineries and Oil } \\
\text { Services Limited }\end{array}$ & 120,000 & 2004 & $\begin{array}{l}\text { Ohali } \\
\text { Ogba }\end{array}$ & Andoni & Rivers \\
\hline 10 & $\begin{array}{c}\text { Ode Aye Refinery } \\
\text { Limited }\end{array}$ & 100,000 & 2004 & Ode Aye & Okiti Pupa & Ondo \\
\hline 11 & $\begin{array}{c}\text { Ologbo Refinery } \\
\text { Company Nigeria } \\
\text { Limited }\end{array}$ & 12,000 & 2010 & Ologbo & Ologbo & Edo \\
\hline 12 & $\begin{array}{l}\text { Orient Petroleum } \\
\text { Resources Limited }\end{array}$ & 55,000 & 2004 & $\begin{array}{l}\text { Aguleri } \\
\text { Out }\end{array}$ & $\begin{array}{l}\text { Anambra } \\
\text { West }\end{array}$ & Anambra \\
\hline 13 & $\begin{array}{c}\text { Owena Oil \& Gas } \\
\text { Limited }\end{array}$ & 60,000 & 2004 & Ilaje & Ilaje & Ondo \\
\hline 14 & $\begin{array}{c}\text { Qua Petroleum Refinery } \\
\text { Limited }\end{array}$ & 100,000 & 2004 & Ibeno & Ibeno & Akwa Ibom \\
\hline 15 & $\begin{array}{l}\text { Rehoboth Natural } \\
\text { Resources Limited }\end{array}$ & 12,000 & 2008 & Immingiri & Yenekoa & Bayelsa \\
\hline 16 & $\begin{array}{l}\text { Resources Refinery \& } \\
\text { Petrochemical Limited }\end{array}$ & 100,000 & 2004 & Ikot Abasi & Ikot Abasi & Akwa Ibom \\
\hline 17 & $\begin{array}{l}\text { Rivgas Petroleum \& } \\
\text { Energy Limited }\end{array}$ & 30,000 & 2004 & $\begin{array}{c}\text { Port } \\
\text { Harcourt }\end{array}$ & Eleme & Rivers \\
\hline 18 & Sapele Refinery Limited & 100,000 & 2004 & $\begin{array}{l}\text { Okpe- } \\
\text { Sobo }\end{array}$ & Sapele & Delta \\
\hline 19 & $\begin{array}{l}\text { South West Refinery \& } \\
\text { Petrochemical Company }\end{array}$ & 100,000 & 2004 & $\begin{array}{l}\text { Ogun- } \\
\text { water side }\end{array}$ & Iwopin & Ogun \\
\hline 20 & Starrex Petroleum & 100,000 & 2004 & Onne & Onne & Rivers \\
\hline
\end{tabular}




$\begin{array}{ccccccc}21 & \text { Tonwei Oil Refinery } & 200,000 & 2002 & \text { Ekeremor } & \text { Ekeremor } \\ 22 & \text { Total Support Limited } & 12,000 & 2004 & \begin{array}{c}\text { Free trade } \\ \text { Zalabar }\end{array} & \begin{array}{c}\text { Bayelsa } \\ \text { Cross River }\end{array} \\ 23 \quad \begin{array}{c}\text { Union Atlantic } \\ \text { Petroleum Ref. }\end{array} & 100,000 & 2002 & \text { Badagry } & \text { Badagry } & \text { Lagos } \\ & & & & & \end{array}$

Source: DPR (2004); NNPC (2008); DPR (2010)

\section{Methodology}

This study involved preparation of detailed emission inventory with estimation of emissions of criteria air pollutants from point sources of existing and proposed refineries in Nigeria. An emission factor approach was used to determine the criteria air pollutant emissions in Nigeria's petroleum refineries and its contribution to the country's airshed.

Detailed information on process unit capacity from the existing and proposed refineries in Nigeria was obtained from previous research reports, company's website and Department of Petroleum Resources (NNPC, 2008; EIA, 2000; US DOE, 2007; DPR 2001; DPR, 2004). The emission factor of criteria pollutants for process units in the petroleum refinery in AP-42 of the United States Environmental protection Agency (US EPA, 1989) was used (Table 3). The process unit capacity was combined with the emission factor of pollutants for each process unit which is calculated as follows;

Table 3. Emission factor of pollutants for process units in petroleum refinery

\begin{tabular}{|c|c|c|c|c|c|c|c|}
\hline \multirow[t]{2}{*}{$\mathrm{S} / \mathrm{N}$} & \multirow[t]{2}{*}{ Process Name } & \multicolumn{6}{|c|}{ Pollutants } \\
\hline & & $\mathrm{PM}_{10}$ & $\mathrm{SO}_{\mathrm{x}}$ & $\mathrm{NO}_{\mathrm{x}}$ & VOC & $\mathrm{CO}$ & Unit \\
\hline 1 & Process Heaters & $7.4 \mathrm{~S}$ & $158.6 \mathrm{~S}$ & 55.0 & 0.3 & 5.0 & 1000 gallons burned \\
\hline 2 & Fluid catalytic cracking unit & - & 493 & 71 & 220 & 13700 & 1000 barrels processed \\
\hline 3 & Flares & - & - & 0.027 & 5.6 & 14.8 & Valve in operation \\
\hline 4 & Boilers & - & $159.3 \mathrm{~S}$ & 67 & - & 5 & 1000 gallons burned \\
\hline
\end{tabular}

"S" means sulphur content "-." means no emission factor for the pollutant.

Source: US EPA (1989)

$$
E=A \times E F_{1}\left[1-\left(\frac{D}{100}\right)\right]
$$

where

$\mathrm{E}=$ Emission Estimate for the Process Unit (tons/yr)

$\mathrm{A}=$ Activity Rate $(\mathrm{bbl} / \mathrm{yr})$

$\mathrm{EF}_{1}=$ Controlled Emission Factor (lbs /bbl)

$\mathrm{D}=\%$ Control Efficiency

Due to lack of information on the level of efficiency of the control device, control efficiency was assumed to be zero for "worst case" scenarios and equation 1 became:

$$
E=A \times E F_{2}
$$

where

$\mathrm{EF}_{2}=$ Uncontrolled emission factor (lbs/bbl)

Total emissions of the criteria pollutants in tons/yr from point sources of existing and proposed refineries were determined using equation (2) and the result is shown in Table 4-5.

\section{Results and Discussion}

The total estimated annual criteria air pollutants from point sources in the existing refineries are 1,217 tons/annum for $\mathrm{PM}_{10}, 45,124$ tons/annum for $\mathrm{SO}_{2}, 167,570$ tons/annum for $\mathrm{NO}_{\mathrm{X},} 3,842$ tons/annum for $\mathrm{VOC}$ and 242,469 tons/annum for $\mathrm{CO}$ (Table 4). An additional 1,082 tons/annum of $\mathrm{PM}_{10}, 168,944$ tons/annum of $\mathrm{SO}_{2}$, 688,687 tons/annum of $\mathrm{NO}_{x}, 9,122$ tons/annum of VOC and 569,975 tons/annum of $\mathrm{CO}$ (Table 5) were predicted to be added into the Nigeria airshed by the proposed petroleum refineries. Since emission rates are directly 
proportional to process unit capacity/ activity rate from equation (2), Tonwei Oil Refinery proposed to operate at $200,000 \mathrm{bbl} / \mathrm{dy}$ will release the maximum emission of air pollutant while Amakpe Refinery, Total Support Refinery, Ologbo Refinery and Rehoboth Refinery proposed to operate at the same capacity of $12,000 \mathrm{bbl} / \mathrm{dy}$ will release the minimum emission of air pollutants. Also, the highest emitting state is Rivers state with the highest number of refineries ( 2 existing and 4 proposed refineries) while the least emitting states are Kaduna, Edo, Lagos and Anambra States (1 existing and 3 proposed refineries respectively) with only 1 refinery in each of the state. The significant point sources of these emissions are fluid catalytic cracking units (FCCU), process heaters, steam boilers and flares. From the criteria pollutants emitted, $\mathrm{CO}$ emission is the highest due to higher rate of incomplete combustion of fuel in the refinery units while particulate matter, which has to do with solid and liquid droplets suspended in air is the least emitted.

Criteria Air Pollutants (CAPs) includes the common air pollutants all over the world which could endanger public health and environment and it originates from various sources in the refinery such as the fluid catalytic cracking units, steam boilers, process heaters and flares e.t.c. (James et al., 2001). The CAPs on its environment indicated the potential for petroleum refinery to create an elevation in ambient concentrations - both indoor and outdoor in Nigeria, though composition could be impacted by local emissions (Zielinska and Fujita, 2003). Na et al. (2001) established a strong link between downtown hydrocarbon levels and nearby petrochemical complex while Kajihara et al. (2003) also noticed a decrease in ambient benzene level with a reduction in benzene concentration discharged into the atmosphere. Possible impacts of anticipated emissions of criteria air pollutants on human (Guo et al., 2004), vegetation (Rao et al., 2001) soil and water (Kim et al., 2001; Johnson et al., 2003) are strong enough for necessary control measures to be implemented in both operating and proposed Nigerian petroleum refineries. The ability to adopt appropriate control measures will determine how much emission of criteria air pollutants will be released into the country's airshed. Both technology and policy control options are recommended in order to reduce the criteria air pollutants in the Nigeria's airshed.

Table 4. Air pollutant emissions from point sources of existing petroleum refinery units

\begin{tabular}{|c|c|c|c|c|c|c|c|}
\hline \multirow[t]{2}{*}{$\mathrm{S} / \mathrm{N}$} & \multirow[t]{2}{*}{ Refinery } & \multirow{2}{*}{$\begin{array}{c}\text { Process } \\
\text { Unit }\end{array}$} & \multicolumn{5}{|c|}{ Criteria pollutant emissions (tons/yr) } \\
\hline & & & $\mathrm{PM}_{10}$ & $\mathrm{SO}_{2}$ & $\mathrm{NO}_{\mathrm{x}}$ & VOC & $\mathrm{CO}$ \\
\hline \multirow[t]{7}{*}{1} & Kaduna Refining & Fluid & - & $1,894.52$ & 274.62 & $8,457.99$ & $52,504.38$ \\
\hline & \& Petrochemical & Catalytic & & & & & \\
\hline & Company & Cracking & & & & & \\
\hline & $(110,000$ bpsd $)$ & $\begin{array}{l}\text { Process } \\
\text { Heaters }\end{array}$ & 73.00 & $1,567.77$ & $6,020.76$ & 34.76 & 549.24 \\
\hline & & Flares & - & - & 0.04 & 0.11 & 0.18 \\
\hline & & Steam & - & $105,771.09$ & $49,365.38$ & - & $3,684.76$ \\
\hline & & Boilers & & & & & \\
\hline \multirow[t]{8}{*}{2} & Port Harcourt & Fluid & - & 434.52 & 69.52 & 194.67 & 12086.71 \\
\hline & Refining & Catalytic & & & & & \\
\hline & Company I & Cracking & & & & & \\
\hline & $(60,000$ bpsd $)$ & Process & 20.85 & 465.81 & 1793.72 & 10.43 & 163.38 \\
\hline & & Heaters & & & & & \\
\hline & & Flares & - & - & 0,011 & 0.03 & 0.07 \\
\hline & & Steam & - & 2071.81 & 9688.14 & - & 723.04 \\
\hline & & Boilers & & & & & \\
\hline \multirow[t]{8}{*}{3} & Port Harcourt & Fluid & - & $3,597.85$ & 517.96 & $1,609.48$ & 100009.99 \\
\hline & Refining & Catalytic & & & & & \\
\hline & Company II & Cracking & & & & & \\
\hline & $(150,000 \mathrm{bpsd})$ & Process & 128.62 & $2,787.90$ & $10,710.15$ & 59.09 & 973.34 \\
\hline & & Heaters & & & & & \\
\hline & & Flares & - & - & 0.07 & 0.14 & 0.05 \\
\hline & & Steam & - & $9,309.24$ & $43,476.71$ & - & $3,246.76$ \\
\hline & & Boilers & & & & & \\
\hline \multirow[t]{4}{*}{4} & Warri Refining \& & Fluid & - & $2,339.47$ & 337.18 & $1,042.86$ & $65,008.25$ \\
\hline & Petrochemical & Catalytic & & & & & \\
\hline & Company & Cracking & & & & & \\
\hline & $(125,000 \mathrm{bpsd})$ & Process & 99.44 & $2,130.90$ & $8,179.48$ & 45.19 & 743.91 \\
\hline
\end{tabular}




\begin{tabular}{ccccccc}
\hline Heaters & & & & & \\
& Flares & - & - & 0.04 & 0.11 & 0.24 \\
& Steam & - & $7,953.52$ & $37,361.46$ & - & 277.40 \\
& Boilers & & & & & \\
Total Emissions & & $1,216.66$ & $45,124.43$ & $167,569.95$ & $3,841.56$ & $242,468.55$ \\
\hline
\end{tabular}

"-" means no emission for the pollutant.

Table 5. Air pollutant emissions from point sources of proposed petroleum refinery units

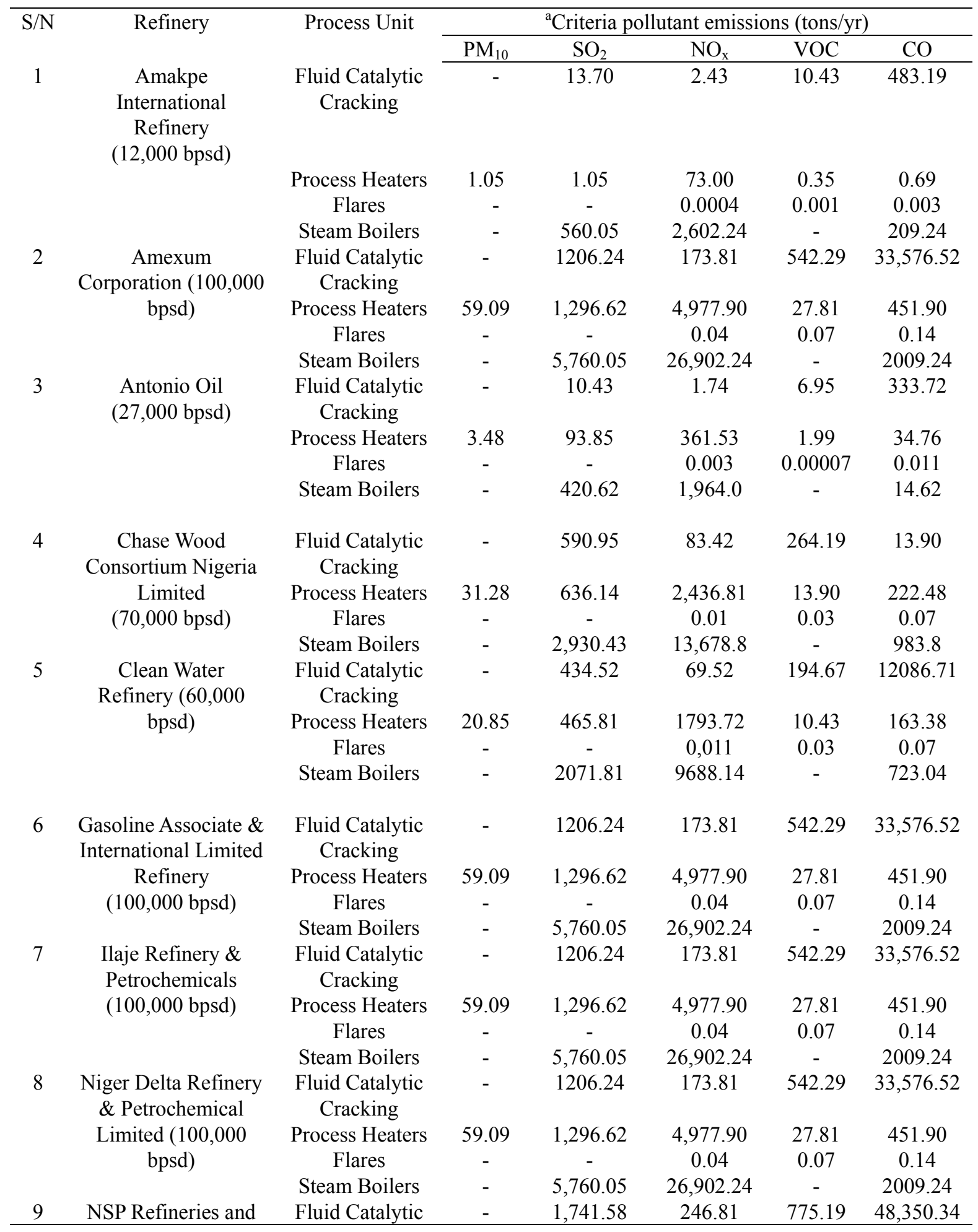




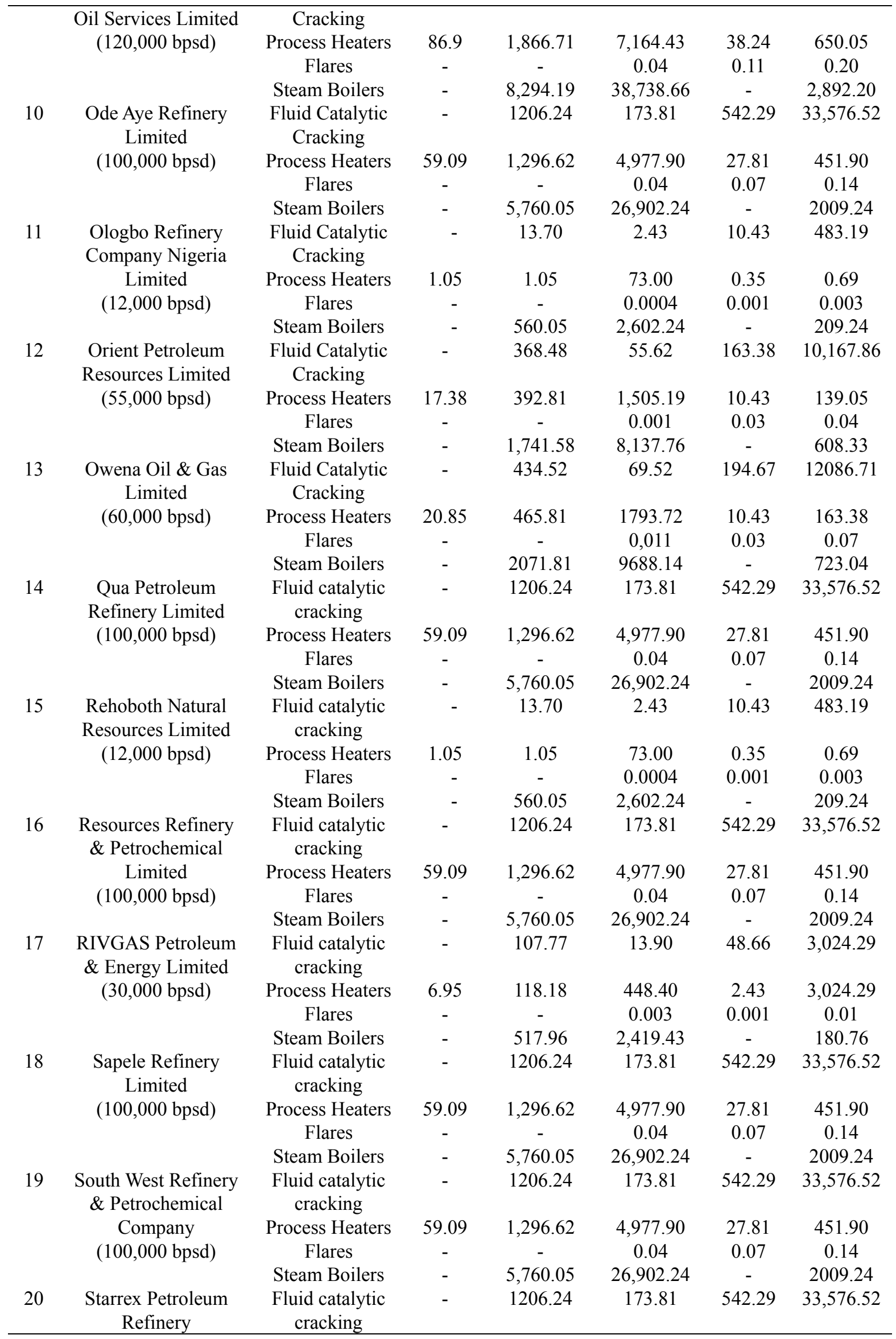




\begin{tabular}{|c|c|c|c|c|c|c|c|}
\hline & $(100,000 \mathrm{bpsd})$ & Process Heaters & 59.09 & $1,296.62$ & $4,977.90$ & 27.81 & 451.90 \\
\hline & & Flares & - & - & 0.04 & 0.07 & 0.14 \\
\hline & & Steam Boilers & - & $5,760.05$ & $26,902.24$ & - & 2009.24 \\
\hline \multirow[t]{4}{*}{21} & $\begin{array}{l}\text { Towei Oil Refinery } \\
(200,000 \text { bpsd })\end{array}$ & $\begin{array}{l}\text { Fluid catalytic } \\
\text { cracking }\end{array}$ & - & $2,158.71$ & 312.85 & 962.91 & $60,006.0$ \\
\hline & & Process Heaters & 229.86 & $5,183.0$ & $19,904.66$ & 107.77 & $1,811.1$ \\
\hline & & Flares & - & - & 0.11 & 0.20 & 0.70 \\
\hline & & Steam Boilers & - & $23,040.20$ & $107,605.47$ & - & $8,033.48$ \\
\hline \multirow[t]{4}{*}{22} & $\begin{array}{c}\text { Total Support } \\
\text { Limited }(12,000\end{array}$ & $\begin{array}{l}\text { Fluid catalytic } \\
\text { crack }\end{array}$ & - & 13.70 & 2.43 & 10.43 & 483.19 \\
\hline & bpsd) & Process Heaters & 1.05 & 1.05 & 73.00 & 0.35 & 0.69 \\
\hline & & Flares & - & - & 0.0004 & 0.001 & 0.003 \\
\hline & & Steam Boilers & - & 560.05 & $2,602.24$ & - & 209.24 \\
\hline \multirow[t]{5}{*}{23} & $\begin{array}{c}\text { Union Atlantic } \\
\text { Petroleum Refinery }\end{array}$ & $\begin{array}{l}\text { Fluid catalytic } \\
\text { crack }\end{array}$ & - & 1206.24 & 173.81 & 542.29 & $33,576.52$ \\
\hline & $(100,000$ bpsd $)$ & Process Heaters & 59.09 & $1,296.62$ & $4,977.90$ & 27.81 & 451.90 \\
\hline & & Flares & - & - & 0.04 & 0.07 & 0.14 \\
\hline & & Steam Boilers & - & $5,760.05$ & $26,902.24$ & - & 2009.24 \\
\hline & \multicolumn{2}{|c|}{ Total Emission (tons/yr) } & $1,081.8$ & $168,943.69$ & $688,687.1$ & $9,121.6$ & $569,975.4$ \\
\hline
\end{tabular}

${ }^{a}$ Calculated by the authors "“-"means no emission factor for the pollutant.

\section{Conclusion and Recommendations}

From the emission inventory carried out in Nigerian petroleum refineries, results revealed that petroleum refinery is one of the major sources of air pollution in Nigeria. The environmental and health impacts of these pollutants indicate that adequate control as to be put place, as more refineries are established, to ensure reduction in the emissions.

Boilers, process heaters, and other process equipment are responsible for the emission of particulates, carbon monoxide, nitrogen oxides $\left(\mathrm{NO}_{\mathrm{x}}\right)$, sulphur oxides $\left(\mathrm{SO}_{2}\right)$, and carbon dioxide $(\mathrm{CO})$. Fluid catalytic cracking units and other units release particulate matters (PM) while Volatile organic compounds (VOCs) are released from storage, product loading and handling facilities and fugitive emissions such as leaks from flanges, valves, seals and drains. These air emissions can be controlled in the refineries by taking the following measures;

i. $\quad \mathrm{NO}_{\mathrm{x}}$ emission reduction can be achieved by replacing furnace burners with low- $\mathrm{NO}_{\mathrm{x}}$ burners and substitution of conventional liquid (nitrogen-containing) fuels with gaseous fuel (nitrogen-free).

ii. $\mathrm{SO}_{2}$ emission reduction can be achieved by the introduction of Clean Fuels (low sulfur) specifications for petrol and diesel to lower sulphur dioxide emissions. Also through desulfurization of fuels or by directing the use of high-sulfur fuels to units equipped with SOx emissions controls

iii. $\mathrm{CO}$ reduction is implemented by controlling the oxygen levels in the $\mathrm{CO}$ burners which is the main source of $\mathrm{CO}$ emissions.

iv. VOC reduction involves the systematic leak detection and repair of any fittings that emit fugitive VOCs by replacing with more reliable equipment, including the environmentally friendly valve design, which tests proved to provide the best seal to prevent VOC fugitive leaks. Also losses from storage tanks and product transfer areas can be reduced by vapour recovery systems and double seals.

v. PM reduction is achieved by installing cyclones on the catalytic cracking unit stacks, this cyclones operate by creating a centrifugal force that physically separates the particulates from the rest of the gas, particulates that would previously have been emitted are now collected from the cyclones and are then available for reuse.

\section{References}

Cape, J. N. (2003). Effects of airborne volatile organic compounds on plants. Environmental Pollution, 122, 145-157.

[DPR] Department of Petroleum Resource. (2001). Nigeria Oil Industry Statistical Bulletin. Department of Petroleum Resources, Ministry of Petroleum Resources, Lagos, Nigeria.

[DPR] Department of Petroleum Resource. (2004). Nigeria Oil Industry Statistical Bulletin. Department of 
Petroleum Resources, Ministry of Petroleum Resources, Lagos, Nigeria.

[DPR] Department of Petroleum Resource. (2010). Private refineries and petrochemical plants status. Nigeria Oil Industry Statistical Bulletin. Department of Petroleum Resources, Ministry of Petroleum Resources, Lagos, Nigeria.

[EIA] Energy Information Administration. (2000). Refinery Capacity Report. Energy Information Administration, Washington, DC.

Gou, H., Lee, S. C., Chan, L. Y., \& Li, W. M. (2004). Risk assessment of exposure to volatile organic compounds in different indoor environments. Environ. Res., 94, 57-66.

James, H., Gary, G., Glenn, E., \& Handwerk, H. (2001) Petroleum Refining: Technology and Economics (4th ed.). CRC Press.

Johnson, R. L., Thomas, T. B., \& Zogorski, J. J. (2003). Effects of daily precipitation and evapotranspiration patterns on flow and VOC transport to groundwater along a watershed flow path. Environmental Science Technology, 37, 4944-4954.

Kajihara, H., Fushimi, A. \& Nakanishi, J. (2003). Verification of the effect on risk due to reduction of benzene discharge. Chemosphere, 53: 285-290.

Kim, H., Annabel, M. D., \& Rao, P. S. (2001). Gaseous transport of volatile organic chemicals in unsaturated porous media: Effect of water partitioning and air-water interfacial adsorption. Environ. Sci. Technol., 35, 4457-4462.

Klieman, K. A. (2012). "U.S. Oil Companies, the Nigerian Civil War, and the Origins of Opacity in the Nigerian Oil Industry", 1(1), 155-165.

Mitra, A. P., \& Sharma, C. (2002). Indian aerosols: present status. Chemosphere, 49, 1175 -1190

Na, K., Moon, K. C., \& Fung, K. (2001). Concentrations of volatile organic compounds in an area of Korea. Atmospheric Eniron, 35, 2747-2756.

[NNPC] Nigeria National Petroleum Corporation. (2008). Warri Refining and Petrochemical Company Limited. Technical Report, 4, 74-76. Retrieved from http://www.osha.gov/dts/osta/otm/otm_iv/otm_iv_html. Retreived February 20, 2012.

Rao, P. S., Gavane, A. G., Ankam, P., Ansari, M. F., Pandit, V. I., \& Nema, P. (2004). Performance evaluation of a green belt in a petroleum refinery: A case study. Ecol. Eng., 23, 77-84

Reinermann, P., \& Golightly, R. (2005). Emission data management. Petroleum quarterly, www.eptq.com. Assessed December 12, 2012.

Sonibare, J. A., Akeredolu, F. A.,Obanijesu E. O., \& Adebiyi, F. M. (2007). Contribution of Volatile Organic Compounds to Nigeria's airshed by Petroleum Refineries. Petroleum Science and Technology, 25, 503-516.

[U.S. DOE] United State Department of Energy. (2007). Energy and Environmental profile of the U.S. Petroleum Refining Industry. Energetics, Inc., Columbia, MD.

[USEPA] United States Environmental Protection Agency. (1989). Airs Facility Subsystem Source Codes and Emission Factor Listing for Criteria Air Pollutants. Research Triangle Park, N.C. U.S. Environmental Protection Agency.

WHO. (2002).The Health Effects of Indoor Air Pollution Exposure in Developing Countries. Publication of the World Health Organization, Geneva, Switzerland. WHO/SDE/OEH/02.05

Zielinska, B., \& Fujita, E. M. (2003). Characterization of ambient volatile organic compounds at the western boundary of the SCOS97-NARSTO Modelling Domain. Atmospheric Environ., 37, 171-180.

Zhonghua, L., Dong, W., \& Sheng, Z. Y. (2003). DNA damage and changes of antioxidative enzymes in chronic benzene poisoning mice. Bin Za Zhi, 21, $423-425$.

\section{Copyrights}

Copyright for this article is retained by the author(s), with first publication rights granted to the journal.

This is an open-access article distributed under the terms and conditions of the Creative Commons Attribution license (http://creativecommons.org/licenses/by/3.0/). 